\begin{tabular}{|c|c|c|}
\hline 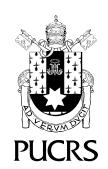 & $\begin{array}{l}\text { ESCOLA DE CIÉNCIAS } \\
\text { DA SAÜDE E DA VIDA }\end{array}$ & $\begin{array}{l}\text { Psico, Porto Alegre, v. 51, n. 2, p. 1-12, abr.-jun. } 2020 \\
\text { e-ISSN: } 1980-8623 \text { | ISSN-L: 0103-5371 }\end{array}$ \\
\hline det $\mathrm{http}: / /$ & doi.org/10.15448/1980-8623.2020.2.30291 & \\
\hline
\end{tabular}

\title{
Oxytocin \& well-being as promoters of affect regulation and homeostasis: a neuroscientific review
}

\author{
Ocitocina \& bem-estar como promotores da regulação afetiva e da homeostase: uma \\ revisão neurocientífica
}

Oxitocina y bienestar como promotores de la regulación del afecto y de la homeostasis: una revisión neurocientífica

\section{Eliana Nogueira-Vale ${ }^{1}$ \\ orcid.org/0000-0002-1975-9370 eliana.vale@uol.com.br}

\section{Nathália Augusta de \\ Almeida ${ }^{1}$}

orcid.org/0000-0002-8794-4586

nathalia_hu@hotmail.com

\section{Marcelo Fernandes \\ Costa $^{1}$}

orcid.org/0000-0002-3944-8457 costamf@usp.br

Recebido em: 4 abr. 2018. Aprovado em: 26 set. 2019 Publicado em: 4 set. 2020.
Artigo está licenciado sob forma de uma licença Creative Commons Atribuição 4.0 Internacional.
Abstract: Context: The term "Well-being" [WB] has many different meanings in scientific literature. Objectives: To search specific situations and related semantics for feelings of well-being [WB] associated to oxytocin [OT] release. Data sources: A systematic review using PRISMA guidelines in PubMed, BVS Virtual (Medline, Lilacs) and SIBI-USP Portal de Busca Integrada (1970-1999 \& 2014-2018). Study selection: Reviews and clinical trials (PICOS) on OT, \& WB and similar concepts in humans. Data extraction: Independent selection of articles by two reviewers; selection of articles by one reviewer, using predefined criteria. Data synthesis: 46 articles were selected out of 339, with 26 additional articles. Main data referred to social situations, sensorial stimuli, trust and psychiatric and health studies. Conclusions: The identified variables involved brain-body-mind interactions, and health/disease; translational neuroscience seems to be the best theoretical reference to investigate it.

Keywords: Oxytocin; Well-being; Translational Neuroscience.

Resumo: Contexto: O termo "Bem-estar" [WB] apresenta muitos significados diferentes na literatura. Objetivos: Buscar situações especificas e semânticas relacionadas a sentimentos de bem-estar [WB] ligados à ocitocina [OT]. Fontes de dados: Revisão sistemática a partir das Referências PRISMA nas bases de dados PubMed, BVS Virtual (Medline, Lilacs) and SIBI-USP Portal de Busca Integrada (1970-1999 \& 2014-2018). Seleção do estudo: revisões e ensaios clínicos (PICOS) sobre OT, \& WB e sinônimos, em humanos. Extração de dados: seleção independente de artigos por dois revisores. Um revisor selecionou os textos utilizando critérios pré-definidos. Sintese dos dados: Dentre 339 artigos, 46 foram selecionados, e mais 26 posteriormente adicionados. Os principais dados obtidos referiam-se a situações sociais, estímulos sensoriais, confiança e estudos psiquiátricos e de saúde. Conclusões: As variáveis identificadas envolveram interações cérebro-corpo-mente e saúde; A neurociência translacional parece ser o melhor referencial teórico para investigá-la.

Palavras-chave: Oxitocina; Bem-estar; Neurociência Translacional.

Resumen: Contexto: El termo "Bienestar" [WB] abarca muchos significados diferentes en la literatura científica. Objetivos: buscar situaciones y semánticas sobre sentimientos de bienestar [WB] asociados con la produccion de oxitocina [OT]. Fuentes de datos: Revisión sistemática en PubMed, BVS Virtual (Medline, Lilacs) y SIBI-USP Portal de Busca Integrada (1970-1999; 2014-2018). Selección de estudios: revisiones y ensayos clínicos (PICOS) en OT, \& WB y sinónimos, en humanos. Extracción de datos: Extracion independiente de artículos por dos revisores; selección de artículos por un revisor, utilizando criterios predefinidos. Sintesis de datos: se seleccionaron 46 artículos dentre 339, y mas 26 adicionales. Los datos principales se referian a situaciones sociales, estimulos sensoriales, confianza y estudios psiquiátricos y de salud. Conclusiones: Las variables identificadas involucraron interacciones cerebro-cuerpo-mente y salud; La neurociencia traslacional parece ser el mejor marco teórico para investigarlo.

Palabras llave: Oxitocina; Bienestar; Neurociencia Traslacional. 
In 2014, the World Health Organization [WHO] declared that "mental health was a state of WB" (https://www.who.int/features/factfiles/mental_ health/en/). The term WB has also been linked to other concepts such as quality of life (SalvadorCarulla, Lucas, Ayuso-Mateos \& Miret, 2014), fitness (Netz, Wu, Becker, \& Tennebaum, 2005), work (Litchfield, Cooper, Hancock, \& Watt, 2016), pain (Gureje, Von Korff, Simon \& Gater, 1998), psychiatry (Kinderman et al, 2015), and spirituality (Azarsa, Davoodl, Markani, Gahramanian, \& Vargaeei, 2015). Non-WB terms such as "antistress" (Uvnas-Moberg, \& Petersson, 2005) and "non-noxious" (Uvnas-Moberg, Handlin, \& Petersson, 2015) have also been used to define WB - that is, the concept is inferred from its opposite, and does not bear a definition of its own. Additionally, WB has been referred to as devoid of a physical, material dimension, and, in this case, is considered as a "psychological" phenomenon. Still other authors consider that physical WB is a component of psychological WB, agreeing that this concept has not yet been clearly defined (Netz et al, 2005).

How to articulate the release of OT with feelings of WB? What would be the specific characteristics of this type of WB? What semantics are used to refer to it? Answering these questions should be of great interest to the health scientist and has led to this review.

Around the 1980s, neuroscientific research started to acknowledge that neuropeptide OT was implicated in the generation of positive moods. The uncovering of neuroendocrine mechanisms revealed that this neuroendocrine primary-process system is typically aroused in the mother during the last months of pregnancy and delivery; and, after birth, both in the mother and the baby, generating pleasurable feelings of WB during their interaction (Panksepp, 1998). The baby usually relaxes upon receiving care, as OT promotes the release of endogenous opioids (Nelson \& Panksepp, 1998). This state of pleasantness and relaxation counteracts many states of painful excitatory arousal, helping the baby to reach an affective, followed by a physiological, regulatory, state (and not the contrary). Mothers are also regulated through interaction with the baby (Schore, 2015).

The articulation of a neuroendocrine mechanism, a correspondent affective mood and a specific behavior results in a "whole" brain-mind-body phenomenon (Panksepp \& Biven, 2012). Accordingly, the authors of this review propose that OT \& WB be considered as a brain-body-mind phenomenon that translates into a healthy, homeostatic balance: as such, a translational neuroscientific approach is suggested to investigate it.

Objectives: to identify in reviews and clinical trials (PICOS, phenomenological and neurobiological characteristics, as well as semantic equivalents, of WB linked to OT, as promoters of affect regulation and homeostasis, following PRISMA Guidelines (Liberati et al, 2009).

\section{Methods}

Study eligibility criteria: terms "OT" \& "WB" and associated semantics were searched in reviews and clinical trials (PICOS), in human studies. Studies on labor, breastfeeding, post-partum, uterine hemorrhages, and animal models, were excluded.

Report eligibility criteria: searches in English language; in titles \& abstracts, when available; on years---1980 to 2000 for early period of History of OT and 2014 to 2018 for present data.

Searches were made in reviews and clinical trials (PICOS), in PubMed, BVS Virtual (Medline, Lilacs) and SIBI-USP Portal de Busca Integrada electronic databases, and by handsearching books of reference and additional articles. The searches were run from February/2018 to August/2019. Eliana Nogueira-Vale and Nathália A. de Almeida made the initial electronic search; and Eliana Nogueira-Vale selected and read the articles and wrote the report; Marcelo da Costa Fernandes supervised the manuscript.

\section{Example of electronic search}

In BVS Virtual (Lilacs \& Medline), an initial search was performed for "OT" AND "WB", yielding 333 results.

Databases: BVS Virtual (MEDLINE $\mathrm{n}=333$ / LILACS=O). Search on OT \& WB. 


\section{Filters}

Main subject: Oxytocin; Type of study: Qualitative Study on Systematic Reviews, CaseControl Studies; Limit: Humans; Idiom: English; Publication years: 2014-2018. Exclusion: postpartum haemorraghe; perinatal depression; maternal depression. Results: (2), with (1) selected:

1. Ma, Y. Shamay-Tsoory, S., Han, S. Z.; \& Caroline, F. (2016). Oxytocin and Social Adaptation: Insights from Neuroimaging Studies of Healthy and Clinical Populations. Trends in Cognitive Science; 20(2):133-145. Article in English | MEDLINE | ID: mdl-26616296 - Excluded because it didn't mention behavioral variables

2. Shalvi, S. De Dreu, C. K. W. (2014). Oxytocin promotes group-serving dishonesty. Proceedings of the National Academy of Sciences U S A; 111(15): 5503-5507. Article in English | MEDLINE | ID: mdl-24706799. Selected.

Eligibility assessment and data collection process were performed by Eliana Nogueira-Vale. Reviews and clinical trials (PICOS), were screened in early (1980-2000) and current periods of OT history (2014-2018), in a search for WB situations and equivalent semantics. Additional data were included for more comprehensive information. Data were organized by categories.

Since this was a qualitative investigation, statistical measures were not applicable.

\section{Synthesis of results}

Results pointed mainly to pleasurable sensorial, social and affiliative stimuli to produce WB (see Tables 2), whether consonant with the release of endogenous OT or with the administration of synthetic intranasal OT. Semantics for WB were retrieved (see Table 3). Variations for age, gender, context and individual profile were found. Psychiatric investigations for OT \& WB are promising but in the beginning. Up to this point of science, OT \& WB would be best studied in a translational neuroscientific approach.

\section{Results}

Study selection: See Table 1 for Flow Diagram.

Study characteristics: this is a qualitative research focused on screening information about situations and equivalent semantics of WB when associated to OT release.

Results in individual studies:

Search on OT \& WB in pioneering literature: because OT was notably well-conserved in mammals during evolution, findings on behavior and emotions of rodents in the 1990's (early History of OT) already anticipated human data (Panksepp, 1998). Initial neuroscientific studies with animal models on OT started around the 1970s (Panksepp, 1998). Around 1987, in Sweden, a group of scientists started researching OT in humans. Pioneer Kirsten Uvnas-Moberg consistently studied OT and other peptides in animals and humans, and has an important role in associating OT \& WB; however, scientific dissemination was difficult in the pre-internet era (see http://WwW. kerstinuvnasmoberg.com/). In parallel, in the USA, an early article on intranasal OT investigation with a sample of PTSD war veterans, was published (Pitman, Orr, Forgue, de Jong, \& Claiborn, 1987), but research with humans only escalated after 2000. At the end of the $20^{\text {th }}$ century, a significant database on OT research with animals had accumulated (Panksepp, 1998), and the implementation of electronic media fostered communication among scientists. In 1992 and 1997, two innovative collections on social influences of OT release in animals were published by The Annals of the New York Academy of Sciences [AAAS] on maternal, sexual and social behaviors (Pedersen \& Caldwell, 1992), and affiliative behavior (Carter, Lederhendler, \& Kirkpatrick, 1997). In 1998, the Oxford University Press published Jaak Panksepp's work on Affective Neuroscience: the foundations of animal and human emotions, which extensively mapped discrete neural circuits in mammals, corresponding to basic affects (Panksepp, 1998). Also, an original issue of Psychoneuroendocrinology Is there a neurobiology of love? was edited by neuroscientists Kirsten Uvnas-Moberg \& C. Sue Carter. Attachment and other social behaviors 
associated to OT release were described as emotional states of calm and positive feelings (Uvnas-Moberg \& Carter (Eds.), 1998). It took another six years for Uvnas-Moberg to start using the term "WB" to designate a diffuse, agreeable background state elicited by massage (UvnasMoberg, 2004). Since then, this term has been widely adopted by OT researchers in human studies. The term WB was not found by the authors of this study in pioneering animal literature on OT; however, similar terms appeared, such as sense of ease, positive erotic feelings, playfulness, feelings of security, positive social memories, peaceful coexistence, flirtatiousness, sexual pleasure and companionship, orgasm, friendship, sleep, yawning, sedation (Panksepp, 1998); love (Panksepp, 1998; Uvnas-Moberg \& Carter, 1998); intimacy, passion, attachment (Nelson \& Panksepp, 1998; Uvnas-Moberg \& Carter, 1998), calm, calmness, relaxation, homeostasis, regulation and anti-stress (Uvnas-Moberg \& Petersson, 2005).

Systematic review on OT \& WB in current scientific literature: many emotional-sensorial stimuli have been associated to OT \& WB, thanks to the evolved endowment of tactile, visual and auditory senses in man, such as changes in the outline of the human face and specialization of facial nerves (Porges, 2011), facilitating affiliative and social activity (Walker \& McGlone, 2013).

Emotional-sensorial categories of stimuli associated to WB \& OT: this kind of stimuli can be widely found in human social and non-social contexts, (Harari-Dahan \& Bernstein, 2014); it should be considered that one stimulus may activate more than one sense at a time. As a social hormone, OT has been associated to WB in many social, sexual, affiliative and care contexts (Carter, 2014; Shalvi \&, De Dreu, 2014); and also in nonsocial situations stimuli, such as psychosomatic manifestations of chills and tearing (crying) in music-listening (Mori \& Iwanaga, (2017). In this search, the following categories associated to OT \& WB were identified:

- Semantic categories (see Table 2)

- Skin stimuli (see Table 3)
Emotion of warmth-liking: this category of emotion was identified as a system of opioidergic modulation activated during interpersonal and close relationships, creating a state of "physiological quiescence, less negative feelings and psychophysiological resilience" (Burgdorf, Rinn \& Stemmler, 2016, p.1712). OT release has been frequently associated to $\mu$ opioids in similar situations (Nelson \& Panksepp, 1998; Nummenmaa et al, 2016), but in that study, it was not cited. One of the authors argued that "more research on OT [concerning the subject] was needed" (e-correspondence between NogueiraVale and Stemmler, October, 29 $\left.{ }^{\text {th }}, 2017\right)$.

Touch: considered one of the most powerful social stimuli, touch is fundamental for child development, attachment and the formation of human bonds (Carter, 2014), producing concomitant feelings of comfort, and behaviors of eye closure and cessation of stress vocalization in mammals; a role for OT release in human intimacy was anticipated in early literature (Panksepp, 1998). In attachment contexts, insistent physical closeness and contact with the mother is sought by young mammals, in a search for feelings of soothing and calmness (Carter, 1998; UvnasMoberg, 1998). In 1990, a special type of lowthreshold, unmyelinated, mechanosensitive, tactile C-afferent fiber [CT-afferent] was identified (Vallbo, Olausson, \& Wessberg 1990), innervating hairy, but not glabrous, human skin, and associated to social touch (Gentsch, Panagiotopoulou, \& Fotopoulou, 2015). Some authors even consider that CT-afferent fibers constitute a specific neurobiological substrate for affect in affiliative behaviors and psychological WB (Walker \& McGlone, 2013), in opposition to the discriminative properties of touch conducted by myelinated nerves (pressure/vibration, temperature, itch and pain) (McGlone, Wessberg, \& Olausson, 2014). CTafferents seem to best respond to gentle stroking touch, stimulating the release of OT (Behnia et al, 2014), endogenous opioids (Nummenmaa et al, 2016), and regulating serotonin (McGlone, Wessberg, \& Olausson, 2014). Its effects translate into increased social motivation and reduced 
reactivity to stressors, leading to feelings of comfort, softness, smoothness, and stress alleviation (Netz, Wu, Becker, \& Tenenbaum, 2005; Ackerley et al, 2014). In romantic relationships, there is enhanced pleasantness when touch comes from the partner, although, some genderspecific variations were found in sexual behavior (Behnia et al, 2014; Ditzen et al, 2013): touch with partner and value of soft interpersonal touch seems to be facilitated by OT, and may contribute to enduring romantic bonds and monogamy (Kreuder et al, 2017). Touch changes social impressions; conversely, facial expression can also alter touch (Ellingsen et al, 2014). Other authors found that high-intensity (Turkeltaub, Yearwood, \& Friedmann, 2014) or moderate intensity kinds of touch (Field. In: Olausson, Wessberg, Morrison, \& McGlone (Eds.), 2016), in opposition to soft touch, would be more effective in relieving stress and bringing relaxation. This apparent contradiction may be due to the social or non-social nature of touch: perhaps in social contexts a specific neural network might be in command for soft affective touch. Indeed, divergent neural processing for touch intensity and pleasantness were found in an fMRI study (Case et al, 2016).

Skin-to-skin contact: skin-to-skin contact with the mother is usually the first one in a newborn's life, and has a primal, ontological role (Nelson \& Panksepp, 1998; Carter, in: Uvnas-Moberg \& Carter, 1998; Porges, 2011). Together with warmth, stroking and massage-like movements of the hand of the mother, it seems to lead to an increase in exchange of glances, smiling and vocalizations, generating feelings of calmness and WB in the baby, improving the quality of later social and affective bonds of the baby (Uvnas-Moberg \& Carter, 1998; Uvnas-Moberg \& Petersson, 2005). In fact, skin-to-skin contact seems to be critical for development (Rilling, 2013), being linked to CT afferents in maternal, affiliative, sexual, and other social contacts, bringing feelings of pleasantness (Kreuder et al, 2015) and influencing social contact; gentle skin-to-skin touch was found to bring acute effects on social evaluation of others (Ellingsen et al, 2014).

Touch and mobile technology: an original article inquired whether contact by means of mobile technology could help in the development of empathy, likely to be related to OT \& WB (Konrath et al, 2015). Would mobile technology lead to a more non-social, elated kind of WB, through the eventual activation of the reward system by keypressing on cell phones, tablets, keyboards, etc.?

Visual stimuli

Eye contact: during development of human attachment, eye-gaze together with touch, constitutes one of the first and most important kinds of social contacts between baby and mother, coinciding with an increase in OT release (Carter, Lederhendler, \& Kirkpatrick, 1997); intranasal OT was also reported to enhance eye-contact in autistic, as well as in normal people (Quattrocki \& Friston, 2014).

Pleasant mental images: the reminiscence of positive memories is associated to OT release, and seems to attenuate acute stress responses, contributing to emotion regulation (Speer \& Delgado, 2017); this elicit positive affect more than positive pictures; OT release, on the other side, can enhance retrieval of positive social memories, attenuating stress feelings (Wudarczyk, Earp, Guastella, \& Savulescu, 2013; Kirsch, 2015).

Face memory/recognition: the human brain was programmed during evolution to preferentially identify and recognize human faces among other visual stimuli (Porges, 2011). OT release improves emotion recognition in faces, the encoding of positive social memories in humans, and recognition of familiar faces identity (Guastella, Mitchell, \& Mathews, 2008).

Auditory stimuli:

Music-listening: Frisson, chills and goosebumps were observed in situations of music-listening (Colver \& El-Alayli, 2015). Would this kind of phenomenon also occur in the appreciation of other aesthetic stimuli? Decreases in blood pressure and heart rate were also observed in coronary male patients, but not in normal men, during music listening; it reduced stress, anxiety and depression, as well as enhanced life satisfaction, optimism, hope and 65meaning in life, more intense in coronary male patients than in healthy man (Gupta \& Gupta, 2015). Conversely, unpleasant 
music seemed to increase anxiety when listened during stress exposure (Jezova et al, 2013).

Music-singing: a recent study relates an improvement in the mood, and a significant immunological increase, but an apparently contradictory finding on decreases in OT and $\beta$-endorphin, in cancer patients after music singing. The hypothesis for that unexpected result was that the decrease represented "a generalized down-regulation of stress response, which may have over-ridden any social bonding or happiness-associated increase" (Fancourt et al, 2016, p.9). However, another study found that OT concentrations increased significantly both in singers after a singing lesson (Grape, Sandgren, Hansson, Ericson, \& Theorell, 2003).

Sounds of infant distress: Adult humans react to sounds and visual cues of infant vulnerability and stress by exhibiting brain amygdala activation (Marsh, 2016). This might be due to the survival value of this kind of alert concerning helpless children.

Shade in nature

An original study found that there was an ideal range of tree shade, promoted by the density of tree canopy, in the recovery from an experimental stress situation in men, but not in women. Density of tree cover showed a dose-response curve in the form of an inverted $U$, assessed by salivary cortisol levels and Trier Social Stress Test. It was also suggested that contact with nature brings WB and health (Jiang, Chang, \& Sullivan, 2014).

Other categories frequently associated with OT \& WB

OT \& WB, and Trust

Trust has been associated to the release of OT \& WB along OT history (Pitman, Orr, Forgue, de Jong, \& Claiborn, 1987; Kosfeld,...Fehr, 2005). In 2013, however, McCullough casted doubt on OT and trust databank (Michael, McCullough, Churchland \& Mendez. 2013); subsequently, in 2015, a critical review also failed to confirm robust evidence in cumulative data, and authors made suggestions to improve rigor in trust research (Nave, Camerer, \& McCullough, 2015).

OT \& WB, and Psychiatry

Considering that many psychiatric diseases bring about negative and unpleasant feelings, biological psychiatry has shown an interest in intranasal OT effects (MacDonald \& Feifel. In: Shalev \& Ebstein (Eds.), 2015). Nonetheless, clinical trials are still incipient, with highlights in the areas of autism (Scheele et al, 2014; Young \& Barrett, 2015); schizophrenia (Fischer-Shofty et al, 2013), depression (Gorgen, Joormann, Hiller, \& Witthoft, 2015); anxiety (Neumann \& Slattery, 2016; and PTSD (Sack et al, 2017). However, sample sizes are frequently modest for statistical validation purposes.

OT \& WB and variations for age, gender, context and individual profile

As with other hormones, OT release in humans seems to decline with age (Elabd et al, 2014). The existence of genetic, neural and sociocognitive processes related to OT release, as well as individual differences in socioemotional processes associated with the OT receptor gene. together with social isolation, may represent a potential risk for depression, social stress, and anxiety in the eldest (Ebner, Maura, Macdonald, Westberg, \& Fischer H, 2013; Emeny et al, 2014). Besides variation on the production of OT with age, variations were also found for gender (Behnia et al, 2014); personality profile (Kelly \& Goodson, 2014), social context (Schladt et al, 2017) and interindividuality (Ollf et al, 2013) in response to OT administration.

OT \& WB and Familiarity

In early OT research, it was demonstrated that OT mediated conditioned place (Liberzon, Trujillo, Akil, \& Young, 1997) and smell preference (Kojima \& Alberts, 2011) in rats. Familiarity is a condition often linked to OT \& WB, as it has an important survival value (De Dreu, Greer, Van Cleef, Shalvi, \& Handgraaf, 2011). It should also be considered the fact that OT is mainly a prosocial and affiliative hormone, having a pivotal importance in attachment processes (Swain et al, 2014), and has shown to be adaptive in situations associated to OT \& WB such as: partner's touch (Bennia et al, 2014), face-memory and prosocial cooperation (Kirsch, 2015), altruism among family, but not other people (Marsh, 2016), caring for ageing people (Ebner et al, 2013), and even promoting dishonesty in behalf of one's group (Shalvi \& 
De Dreu, 2014). The neurobiological common ground for these different situations of familiarity is probably linked to vagal activation, which occurs in situations of proximity without fear, inhibiting visceral activation (Porges, 2011), and contributing to affective regulation (Schore, 2015).

\section{Synthesis of results}

The main variables associated to OT \& WB found in this review refer to social situations, sensorial stimuli, and trust. Variations according to gender, age, familiarity, individual profile and context were found for the studied variables.

\section{Discussion}

\section{Summary of evidence}

Many semantic categories for WB found in animal pioneering research are applicable to human beings, especially those concerning attachment variables. It should be considered that recent developments in neuroscience have allowed for more comprehensive data on humans. Among screened studies, most salient variables associated to WB were: sensorial stimuli, feelings of trust, companionship, and heterosexual couples. Psychiatric studies emphasized the lack of WB in psychiatric disorders. More studies on OT \&WB in psychiatry, with more scientific power, are needed. Among screened emotional stimuli likely to be associated to WB, there were mentioned tactile, auditory \& visual stimuli, and shade/ luminosity. In spite of prior acceptance of OT \& WB associated to trust, recent critical reviews found inconclusive results, suggesting new strategies for research. When selecting samples, attention should be given to variations in gender, individual profile, age, contexts and familiarity.

\section{Limitations}

This research was limited for being partly performed by a single reviewer. Another limitation refers to the small temporal span of the research. Considering that central OT discoveries date from the 1980's, and the advent of intranasal OT dates from 2000, a more exhaustive research would be advisable. The subjects selected by the authors for this discussion may have left other relevant points aside.

\section{Conclusions}

Feelings, emotions and sensations of WB found in this research were mainly related to sensorial and social stimuli, or a blend of the two of them. For better results, a more exhaustive data retrieval would be desirable. The best methodological approach for this kind of study would be a translational research. The retrieved semantic categories for WB could be of use in favor of the construction of a scale, associating OT \& WB.

\section{Funding}

This project was financially supported by CAPES (Coordenação de Aperfeiçoamento de Pessoal de Nivel Superior).

\section{Acknowledgements}

The authors would like to thank Avelino Luiz de Oliveira for reviewing the initial version of this article.

\section{Disclosures}

The authors have no conflict of interests to declare.

\section{References}

Ackerley, R., Wasling H. B. ... Wessberg, J. (2014). Human C-Tactile Afferents Are Tuned to the Temperature of a Skin-Stroking Caress. The Journal of Neuroscience, 34(8): 2879 -2883. doi: 10.1523/JNEUROSCI.2847-13.2014

Azarsa, T., Davoodi, A., Markani, A. K., Gahramanian, A. \& Vargaeei, A. (2015). Spiritual wellbeing, attitude toward spiritual care and its relationship with spiritual care competence among critical care nurses. Journal of Caring Sciences, 4(4):309-320. doi: 10.15171/jcs.2015.031

Behnia, B., Heinrichs, M., Bergmann, W., Jung, S., Germann, J., Schedlovsky, M.,...Kruger, T. H. (2014). Differential effects of intranasal oxytocin on sexual experiences and partner interactions in couples. Hormonal Behavior, 65(3):308-18. doi: 10.1016/j.yhbeh.2014.01.009.

Burgdorf, C., Rinn, C., \& Stemmler, G. (2016). Effects of personality on the opioidergic modulation of the emotion warmth-liking. Journal of Comparative Neurology, 524(8):1712-26. 10.1002/cne.23847 
Carter, C. S. (2014). Oxytocin pathways and the evolution of human behavior. Annual Review of Psychology, 65:1739. 10.1146/annurev-psych-010213-115110.

C. S. Carter, I. I. Lederhendler, \& B. Kirkpatrick. (Eds.), (1997). The integrative neurobiology of affiliation. The Annual New York Academy of Sciences, 807. 10.1111/ j.1749-6632.1997.tb51909.x

Carter, C. S. (1998) Neuroendocrine perspectives on social attachment and love. In: K. Uvnas-Moberg \& C. S. Carter (Guest Eds.). Is there a neurobiology of love? Psychoneuroendocrinology, 23(8):779-818. 10.1016/ S0306-4530(98)00055-9

Case, L. K., Laubacher, C. M., Olausson, H., Wang, B., Spagnolo, P. A., \& Bushnell, M. C. (2016). Encoding of touch intensity but not pleasantness in human primary somatosensory cortex. The Journal of Neuroscience, 36(21):5850-5860. doi: 10.1523/JNEUROSCI.1130-15.2016

Colver, M. C., \& El-Alayli, A. (2015). Getting aesthetic chills from music: The connection between openness to experience and frisson. Psychology of Music, 44(3):413 - 427. doi.org/10.1177/0305735615572358

De Dreu, C. K. W, Greer, L. L., Van Cleef, G. A., Shalvi, S., \& Handgraaf, J. J. (2011). Oxytocin promotes human ethnocentrism. PNAS, 108(4):1262-1266. 10.1073/pnas.1015316108

Ditzen, B., Nater, U. M., Schaer, M., La Marca, R., Bodenmann, G., Ehlert, U.,... Heinrichs, M. (2013). Sex-specific effects of intranasal oxytocin on autonomic nervous system and emotional responses to couple conflict. Social Cognitive and Affective Neuroscience, 8(8):897-902. 10.1093/scan/nss083

Ebner, N. C., Maura, G. M., Macdonald, K., Westberg, L., \& Fischer, H. (2013). Oxytocin and socioemotional aging: current knowledge and future trends. Frontiers of Human Neuroscience, 7:487. doi: 10.3389/fnhum.2013.00487. E-correspondence between Eliana Nogueira-Vale and Gerhard Stemmler, October, $29^{\text {th }}, 2017$.

Elabd, C., Cousin, W., Upadhyayula, P., Chen, R.Y., Chooljian, M. S., Li, J. et al. (2014). Oxytocin is an age-specific circulating hormone that is necessary for muscle maintenance and regeneration. Nature Communications, 5:4082. 10.1038/ncomms5082

Ellingsen, D.-M., Wessberg, J., Chelnokova, O., Olausson, H., Laeng, B. \& Leknes, S. (2014). In touch with your emotions: oxytocin and touch change social impressions while others' facial expressions can alter touch. Psychoneuroendocrinology 39:11-20. 10.1016/j. psyneuen.2013.09.017

Emeny, R. T., Huber, D., Bidlingmaier, M., Reincke, M., Klug, G. \& Ladwig, K. H. (2015). Oxytocin-induced coping with stressful life events in old age depends on attachment: findings from the cross-sectional KORA Age Study. Psychoneuroendocrinology, 56:132-42. doi: 10.1016/j.psyneuen.2015.03.014

Fancourt, D., Williamon, A., Carvalho, L. A., Steptoe, A., Dow, R., \& Lewis, I. (2016). Singing modulates mood, stress, cortisol, cytokine and neuropeptide activity in cancer patients and carers. Ecancermedicalscience, 10:631. doi:10.3332/ecancer.2016.631.
Field, T. (2016). Moderate pressure massage therapy. In: $\mathrm{H}$. Olausson, J. Wessberg, I. Morrison \& F. McGlone. (Eds). (2016). Affective touch and neurophysiology of CT afferents. New York, NY, EUA: Springer. doi: 10. 1007/978-1-4939-6418-5_12

Fischer-Shofty, M., Brüne, M., Ebert, A., Shefet, D., Levkovitz, Y., \& Shamay-Tsoory, S. G. (2013). Improving social perception in schizophrenia: the role of oxytocin. Schizophrenia Research,146(1-3):357-62. doi: 10.1016/j. schres.2013.01.006.

Gentsch, A., Panagiotopoulou, E., \& Fotopoulou, A. (2015). Active interpersonal touch gives rise to the social softness illusion. Current Biology, 25(18): 2392-2397. doi: 10.1016/j.cub.2015.07.049

Gorgen, S. M., Joormann, J., Hiller, W. \& Witthoft, M. (2015). The role of mental imagery in depression: negative mental imagery induces strong implicit and explicit affect in depression. Frontiers of Psychiatry, 6:94. doi: 10.3389/fp-syt.2015.00094

Grape, C., Sandgren, M., Hansson, L. O., Ericson, M. \& Theorell, T. (2003). Does singing promote well-being?: an empirical study of professional and amateur singers during a singing lesson. Integrative Physiological and Behavioral Science, 38(1):65-74. doi: 10.1007/BF02734261

Guastella, A. J., Mitchell, P. B., \& Mathews, F. (2008). Oxytocin enhances the encoding of positive social memories in humans. Biological Psychiatry, 64(3):256258. doi:10.1016/j.biopsych.2008.02.008.

Gupta, U. \& Gupta, B. S. (2015). Psychophysiological reactions to music in male coronary patients and healthy controls. Psychology of music, 43(5):736-755. doi: 10.1177/0305735614536754

Gureje, O., Von Korff, M., Simon, G. E., \& Gater, R. (1998). Persistent pain and well-being: a World Health Organization Study in Primary Care. JAMA. 280(2):147-51. doi:10.1001/jama.280.2.147.

Harari-Dahan, O. \& Bernstein, A. (2014). A general approach-avoidance hypothesis of oxytocin: accounting for social and non-social effects of oxytocin. Neuroscience and Biobehavioral Reviews, 47:506-519.doi: 10.1016/i.neubiorev.2014.10.007 http://www.kerstinuvnasmoberg.com/ http://www.who.int/features/factfiles/mental_health/en/

IsHak, W. W., Kahloon, M., \& Fahkry, H. (2011). Oxytocin role in enhancing well-being: a literature review. Journal of Affective Disorders, 130:1-9. doi: 10.1016/ij.jad.2010.06.001

Jezova, D., Hlavacova, N., Makatsori, A., Duncko, R., Loder, I., \& Hinghofer-Szalkay, H. (2013). Increased anxiety induced by listening to unpleasant music during stress exposure is associated with reduced blood pressure and ACTH responses in healthy men. Neuroendocrinology, 98(2):144-50. doi: 10.1159/000354202

Jiang, B., Chang, C.-Y. \& Sullivan, W. C. (2014). A dose of nature: tree cover, stress reduction, and gender differences. Landscape and Urban Planning, 132:26-36. doi.org/10.1016/j.landurbplan.2014.08.005

Kelly, A. M., \& Goodson, J. L. (2014). Personality is tightly coupled to vasopressin-oxytocin neuron activity in a gregarious finch. Frontiers of Behavioral Neuroscience. 8:55. doi: 10.3389/fnbeh.2014.00055 
K. Uvnas-Moberg, \& C. S. Carter (Guest Editors). (1998). Editorial: Is there a neurobiology of love? Psychoneuroendocrinology. 23(8):749-750. doi 10.1016/S0306-4530(98)00055-9

Kinderman, P., Tai, S., Pontin, E., Schwannauer, M., Jarman, I., \& Lisboa, P. (2015). Causal and mediating factors for anxiety, depression and well-being. British Journal of Psychiatry, 206(6):456-460. doi: 10.1192/bjp.bp.114.147553

Kirsch, P. (2015). Oxytocin in the socioemotional brain: implications for psychiatric disorders. Dialogues in Clinical Neuroscience, 17(4):463-76. License CC BY-NC-ND 3.0. Retrieved from https://www.researchgate.net/publication/301283709_Oxytocin_in_the_socioemotional_brain_ Implications_for_psychiatric_disorders. doi nonexistent.

Kojima, S., \& Alberts, J. R. (2011). Oxytocin mediates the acquisition of filial, odor-guided huddling for maternally-associated odor in preweanling rats. Hormonal Behavior, 60(5):549-58. doi: 10.1016/j.yhbeh.2011.08.003

Konrath, S., Falk, E., Fuhrel-Forbis, A., Liu, M., Swain, J., Tolman R., ...Walton, M. (2015). Can text messages increase empathy and prosocial behavior? The development and initial validation of Text to Connect. PLOS ONE, 1O(g): e0137585. doi 10.1371/journal.pone.0137585.

Kosfeld, M., Heinrichs, M., Zak, P. J., Fischbacher, U., \& Fehr, E. (2005). Oxytocin increases trust in humans, Nature, 435(7042):673-676. doi: 10.1038/nature03701

Kreuder, A. K., Scheele, D., Wassermann, L., Wollseifer, M., Stoffel-Wagner, B., Lee, M. R.,... Hurlemann, R. (2017). How the brain codes intimacy: The neurobiological substrates of romantic touch. Human Brain Mapping, 38(9):4525-4534. doi: 10.1002/hbm.23679

Liberati, A., Altman, D. G., Tetzlaff, J., Mulrow, C., Getzsche, P. C., loannidis, J. P. A.,... Moher, D. (2009). The PRISMA Statement for reporting systematyc reviews and meta-analyses of studies that evalutate health care interventions: explanation and elaboration. PLOS Medicine, 6(7): e1000100. doi 10.1371/journal.pmed.1000100

Liberzon, I., Trujillo, K. A., Akil, H. \& Young, E. A. (1997). Motivational properties of oxytocin in the conditioned place preference paradigm. Neuropsychopharmacology, 17(6):353-359. doi.org/10.1016/S0893-133X(97)00070-5

Litchfield, P., Cooper, C., Hancock, C., \& Watt, P. (2016). Work and wellbeing in the 21st century. International Journal of Environmental Research and Public Health, 13(11):1065. doi: 10.3390/ijerph13111065

MacDonald, K., \& Feifel, D. (2015). Helping oxytocin deliver: considerations in the development of oxytocin-based therapeutics for brain disorders. In: I. Shalev \& R. P. Ebstein, (Eds.) Social hormones and human behavior: what do we know and where do we go from here. Frontiers in Neuroscience, 7(35):42-62. doi.org/10.3389/fnins.2013.00035

Marsh, A. A. (2016) Neural, cognitive, and evolutionary foundations of human altruism. Wiley Interdisciplinary Review of Cognitive Science, 7(1):59-71. doi: 10.1002/wcs.1377

McCullough, M. E., Churchland, P. S., \& Mendez, A. J. (2013). Problems with measuring peripheral oxytocin: can the data on oxytocin and human behavior be trusted? Neuroscience and Biobehavioral Reviews, 37(8):1485-1492. doi: 10.1016/j.neubiorev.2013.04.018.
McGlone, F., Wessberg, J., \& Olausson, H. (2014). Discriminative and affective touch: sensing and feeling Neuron, 82(4):737-55. doi: 10.1016/j.neuron.2014.05.001.

Michael, E., McCullough, M. E., Churchland, P. S., \& Mendez, A. J. (2013). Problems with measuring peripheral oxytocin: Can the data on oxytocin and human behavior be trusted? Neuroscience and Biobehavioral Reviews, 37:1485- 1492. doi: 10.1016/j.neubiorev.2013.04.018

Moher, D., Shamseer, L., Clarke, M. et al. Preferred reporting items for systematic review and meta-analysis protocols (PRISMA-P) 2015 statement. Syst Rev 4, 1 (2015). https://doi.org/10.1186/2046-4053-4-1

Mori, K. \& Iwanaga, M. (2017). Two types of peak emotional responses to music: The psychophysiology of chills and tears. Scientific Reports. 7:46063. doi 10.1038/srep46063

Nave, G., Camerer, C., \& McCullough, M. (2015) Does oxytocin increase trust in humans? A critical review of research. Perspectives on Psychological Science, 10(6):772-89. doi: 10.1177/1745691615600138

Nelson E. E., \& Panksepp, J. (1998). Brain substrates of infant-mother attachment: contributions of opioids, oxytocin, and norepinephrine. Neuroscience and Biobehavioral Reviews, 22(3):437-452. doi: 10.1016/S0149-7634(97)00052-3

Netz, Y., Wu, M.-J., Becker, B. J., \& Tenenbaum, G. (2005). Physical activity and psychological well-being in advanced age: a meta-analysis of intervention studies. Psychology and Aging, 20(2):272-284. doi: 10.1037/0882-7974.20.2.272

Neumann, I. D. \& Slattery D. A. (2016). Oxytocin in general anxiety and social fear: A translational approach. Biological Psychiatry, 79(3):213-221. doi: 10.1016/j.biopsych.2015.06.004

Nummenmaa, L., Tuominen, L., Dunbar, R., Hirvonen, J., Manninen, S., Arponen, E.,...Sams, M. (2016). Social touch modulates endogenous $\mu$-opioid system activity in humans. Neuroimage, 138:242-247. doi: 10.1016/j. neuroimage.2016.05.063

Olff, M., Frijling, J. L., Kubzansky, L. D., Bradley, B., Ellenbogen, M. A., Cardoso C,...van Zuiden, M. (2013). The role of oxytocin in social bonding, stress regulation and mental health: an update on the moderating effects of context and interindividual differences. Psychoneuroendocrinology, 38(9):1883-1894. doi: 10.1016/j. psyneuen.2013.06.019

Panksepp, J. (1998). Affective Neuroscience: the foundations of human and animal emotions. New York, NY, EUA: Oxford University Press. ISBN-13: 978-0195178050 ISBN-10: 019517805X

Panksepp, J. \& Biven, L. (2012). The archaeology of mind: neuroevolutionary origins of human emotions. New York NY, EUA: Norton Series on Interpersonal Neurobiology.

Pedersen, C. A., Caldwell, J. D., Jirikowski, G. F., \& Insel, T. R (Eds). (1992). Oxytocin in maternal, sexual and social behaviors. Annals of the New York Academy of Sciences. 652:1-492. doi.org/10.1111/j.1749-6632.1992.tb34346.x 
Pitman, R. K., Orr, S. P., Forgue, D. F., de Jong, J. B. \& Claiborn, J. M. (1987) Psychophysiologic assessment of posttraumatic stress disorder imagery in Vietnam combat veterans. Archives of General Psychiatry, 44(11):970-975. doi: 10.1001/archpsyc.1987.01800230050009.

Porges, S. W. (2011). The polyvagal theory: neurophysiological foundations of emotions, attachment, communication self-regulation. New York, NY, EUA: WW Norton \& Co.

Quattrocki, E. \& Friston, K. (2014). Autism, oxytocin and interoception. Neuroscience and Biobehavioral Reviews, 47:410-430. doi: 10.1016/j.neubiorev.2014.09.012

Rilling, J. K. (2013). The neural and hormonal bases of human parental care. Neuropsychologia. 51(4):731-47. doi: 10.1016/j.neuropsychologia.2012.12.017

Sack, M., Spieler, D., Wizelman, L., Epple, G., Stich, J., Zaba, M., \& Schmidt, U. (2017). Intranasal oxytocin reduces provoked symptoms in female patients with posttraumatic stress disorder despite exerting sympathomimetic and positive chronotropic effects in a randomized controlled trial. BMC Medicine, 15(1):40. doi: 10.1186/s12916-017-0801-0.

Salvador-Carulla, L., Lucas, R., Ayuso-Mateos, J. L., \& Miret, M. (2014). Use of the terms "Wellbeing" and "Quality of Life" in health sciences: a conceptual framework. European Journal of Psychiatry, 28(1):50-65. doi: 10.4321/ S0213-61632014000100005

Scheele, D., Kendrick, K. M., Khouri, C., Kretzer, E., Schläpfer, T. E., Stoffel-Wagner. B.,... Hurlemann, R. (2014). An oxytocin-induced facilitation of neural and emotional responses to social touch correlates inversely with autism traits. Neuropsychopharmacology, 39(9):2078-85. doi: $10.1038 / \mathrm{npp} .2014 .78$

Schladt, T. M., Nordmann, G.C., Emilius, R., Kudielka, B. M., de Jong, T.R. \& Neumann, I.D. (2017). Choir versus solo singing: effects on mood, and salivary oxytocin and cortisol concentrations. Frontiers of Human Neuroscience, 11: 430. doi:10.3389/fnhum.2017.00430

Schore, A. J. (2015) Affect regulation and the origin of the self: the neurobiology of emotional development. New York, NY, EUA: Routledge. https://doi. org/10.4324/9781315680019

Shalvi, S. De Dreu, C. K. W. (2014). Oxytocin promotes group-serving dishonesty. Proceedings of the National Academy of Sciences U S A; 111(15): 5503-5507. doi. org/10.1073/pnas.1400724111

Shamay-Tsoory, S.; Young, L. J. (2016). Understanding the oxytocin system and its relevance to psychiatry. Biological Psychiatry, 79(3):150-152. doi: 10.1016/j.biopsych.2015.10.014

Speer, M. E. \& Delgado, M.R. (2017). Reminiscing about positive memories buffers acute stress responses. Nature Human Behaviour, 1:0093. doi:10.1038/s41562-017-0093

Swain, J. E., Kim, P., Spicer, J., Ho, S. S., Dayton, C. J., Elmadih, A.,...Abel, K. M. (2014). Approaching the biology of human parental attachment: brain imaging, oxytocin and coordinated assessments of mothers and fathers. Brain Research, 1580:78-101. doi: 10.1016/j. brainres.2014.03.007
Turkeltaub, P. C., Yearwood, E. \& Friedmann, E. (2014). Effect of a brief seated massage on nursing student attitudes toward touch for comfort care. The Journal of Alternative and Complementary Medicine, 20(10):792-799. doi.org/10.1089/acm.2014.0142

Uvnas-Moberg, K. (1998). Oxytocin may mediate the benefits of positive social interaction and emotions. In: K. Uvnas-Moberg and C. S. Carter (Guest Eds.). Is there a neurobiology of love? Psychoneuroendocrinology, 23(8):819-835. doi 10.1016/S0306-4530(98)00055-9

Uvnas-Moberg, K. (2004). Massage and wellbeing, an integrative role for oxytocin? In: Field, T. (Ed.). Touch in labour and infancy. Cary, North Carolina, EUA: J\&J Publishing, LCC.

Uvnas-Moberg, K. \& Petersson, M. (2005). Oxytocin, a mediator of anti-stress, well-being, social interaction, growth and healing. Journal of Psychosomatic Medicine and Psychotherapy, 51(1):57-doi: 10.13109/zptm.2005.51.1.57

Uvnas-Moberg, K., Handlin, L. \& Petersson, M. (2015). Self-soothing behaviors with particular reference to oxytocin release induced by non-noxious sensory stimulation. Frontiers of psychology, 5:1529. doi: 10.3389/ fpsyg.2014.01529

Vallbo, A. B., Olausson, H. \& Wessberg, J (1990). Unmyelinated afferents constitute a second system coding tactile stimuli of the human hairy skin. Journal of Neurophysiology, 81:2753-2763. doi:10.1152/jn.1999.81.6.2753

Walker, S. C. \& McGlone, F. P. (2013). The social brain: neurobiological basis of affiliative behaviours and psychological well-being. Neuropeptides, 47(6):379-393. doi: 10.1016/j.npep.2013.10.008.

Wudarczyk, O. A., Earp, B. D., Guastella, A. \& Savulescu, J. (2013). Could intranasal oxytocin be used to enhance relationships? Research imperatives, clinical policy, and ethical considerations. Current Opinion in Psychiatry, 26(5):474-484. doi: 10.1097/YCO.0b013e3283642e10

Young, L. J., \& Barrett, C. E. (2015). Neuroscience. Can oxytocin treat autism? Science, 347(6224):825-826. doi:10.1126/science.aaa8120

\section{Eliana Nogueira-Vale}

Titulação Acadêmica: Doutora em Neurociência e Comportamento

Afiliação Institucional: Departamento de Psicologia Experimental. Núcleo de Neurociência e Comportamento e Neurociência Aplicada [PSE - NEC]. Laboratório de Psicofisiologia Sensorial. Instituto de Psicologia da Universidade de São Paulo. São Paulo, SP, Brasil.

\section{Nathália Augusta de Almeida}

Titulação Acadêmica: Mestre em Psicologia Clínica

Afiliação Institucional: Departamento de Psicologia Clínica [PSC]. Membro do Laboratório Sujeito e Corpo (SuCor) e do Grupo de Pesquisas CNPq. Projeto Guarda-Chuva - SuCor Práticas Clínicas em Psicossomática. Instituto de Psicologia da Universidade de São Paulo, São Paulo, SP, Brasil. 


\section{Marcelo Fernandes Costa}

Titulação Acadêmica: Professor Associado II em Psicologia Sensorial e da Percepção; Chefe Suplente do Departamento de Psicologia Experimental; Coordenador do Programa de Pós-Graduação em Neurociência e Comportamento do Instituto de Psicologia (CAPES 5) (CAPES 7): Chefe do Laboratório de Psicofisiologia Sensorial.

Afiliação Institucional: Departamento de Psicologia Experimental. Psicologia Sensorial e da Percepção. Núcleo de Neurociência e Comportamento e Neurociência Aplicada [PSE - NEC]. Programa de Pós-Graduação em Neurociência e Comportamento do Instituto de Psicologia, Laboratório de Psicofisiologia Sensorial. Instituto de Psicologia da Universidade de São Paulo, São Paulo, SP, Brasil.

\section{Mailing Address:}

Eliana Nogueira-Vale

Universidade de São Paulo

Avenida Professor Mello de Morais, 1721

Butantã 05508-030

São Paulo, SP, Brasil

Table 1 -PRISMA 2009 Flow Diagram (1): Oxytocin \& Well-being - Systematic Review

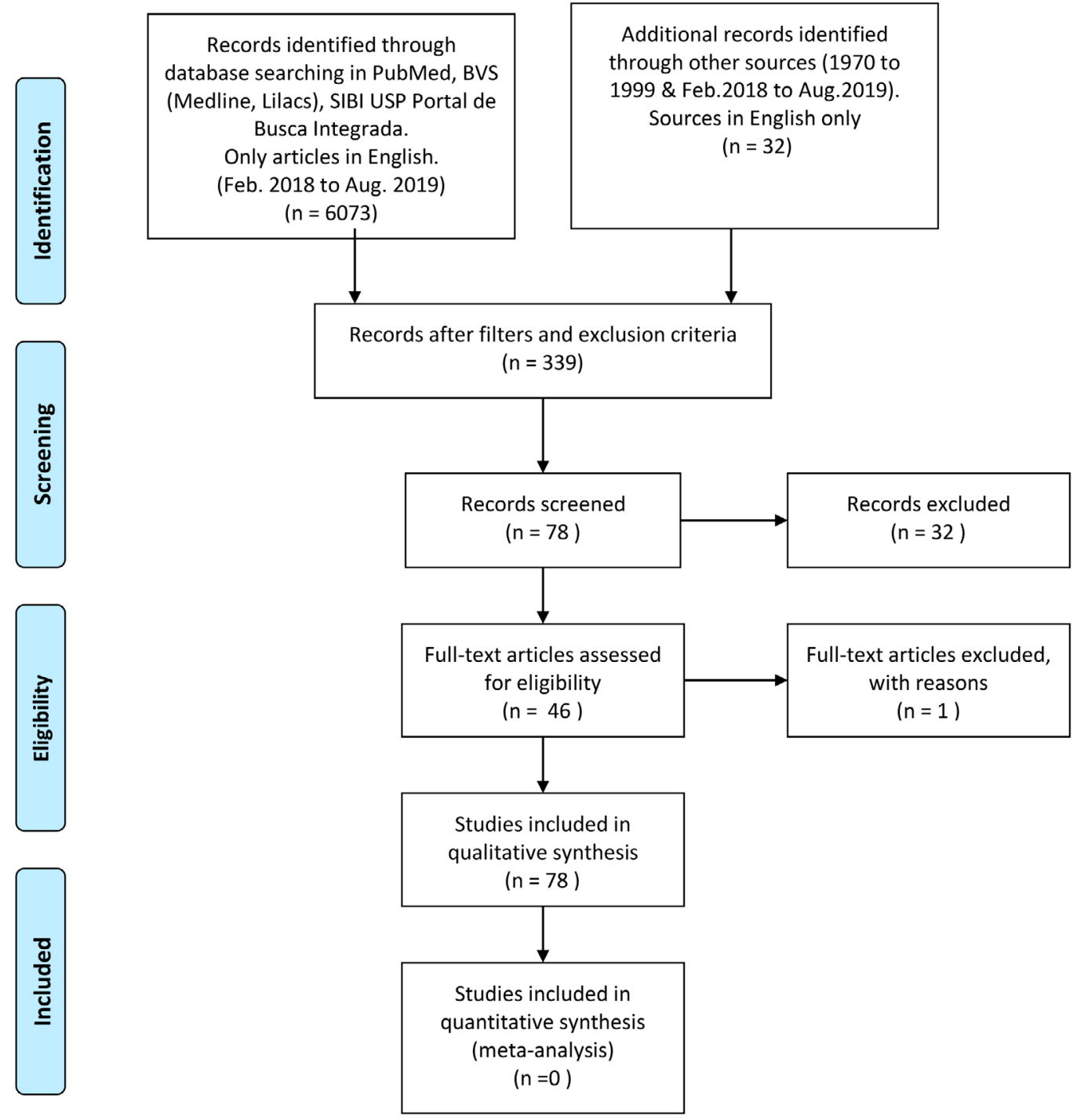


Table 2 - Semantic equivalents and Categories of WB retrieved in this review

Source

Semantic Equivalents \& Categories for Emotions/ feelings
Comfort, flirtatiousness, friendship, peaceful coexistence, playfulness positive erotic feelings, positive social memories, sense of ease, orgasm, security, sedation, sexual pleasure, sleep, yawning

Attachment, closeness, intimacy, passion, soothing

Love

Anti-stress, calm, calmness, homeostasis, relaxation

Affect regulation

Frisson, chills and goose-bumps

Reduction of stress, depression, anxiety; enhanced life satisfaction, optimism, hope and meaning in life

Quiescence, resilience

Table 3 - Summary of skin stimuli categories and semantic equivalents for WB

\section{Source}

- Burgdorf, Rinn \& Stemmler, 2016

- Panksepp, 1998

- Uvnas-Moberg, 1998

- Carter, 2014

Nummenmaa et al, 2016

- Vallbo, Olausson, \& Wessberg 1990

- Netz, Wu, Becker, \& Tenenbaum,

2005

- Walker \& McGlone, 2013

- Behnia et al, 2014

- Ditzen et al, 2013

- Turkeltaub, Yearwood, \& Friedmann, 2014

- Field. In: Olausson, Wessberg, Morrison, \& McGlone (Eds.), 2016

- Uvnas-Moberg \& Carter, 1998;

- Uvnas-Moberg \& Petersson, 2005

- Kreuder et al, 2015
Categories of variables for touch

Emotion of warmth-liking

Soft touch

CT-afferents

Romantic relationships

Touch of high-intensity or moderate intensity

Skin-to-skin contact

\section{Semantic Equivalents for Emotions/ feelings}

Physiological quiescence, less negative feelings and psychophysiological resilience

Comfort, soothing and calmness

Comfort, softness, smoothness, and stress alleviation

Affect in affiliative behaviors, well-being

Pleasantness

Relieve stress \& bring relaxation

Calmness and WB; affective-emotional pleasantness 